\title{
Anne Bekçiliği Ölçeği Anne Formunun Türkçeye Uyarlanması: Geçerlik ve Güvenirlik Çalışması
}

\author{
Güleycan Akgöz Aktaş \\ Mersin Üniversitesi
}

\author{
Arzu Aydin \\ Mersin Üniversitesi
}

\section{Özet}

Bu çalışmada, annelerin babalar üzerindeki teşvik edici, kontrolcü ve kısıtlayıcı davranışlarının değerlendirilebilmesi amaciyla geliştirilen 42 maddelik Anne Bekçiliği Ölçeği Anne Formu (ABÖ-A) Türkçeye uyarlanarak geçerlik ve güvenirlik açısından incelenmiştir. Araştırmaya 4-6 yaş arası çocuğa sahip toplamda 210 anne katılmıştır. Yapı geçerliğini belirleyebilmek için yürütülen doğrulayıcı faktör analizi ABÖ-A'nın orijinal ölçek ile uyumlu olarak üç faktörlü yapıya sahip olduğunu göstermiştir. ABÖ-A'nın kriter geçerliğinin belirlenmesi için kullanılan Baba Katı$1 ı \mathrm{~m}$ Ölçeği (BAKÖ) ile korelasyon katsayıları anlamlı ve beklenen yöndedir. ABÖ-A'nın alt ölçeklerinin kabul edilebilir düzeyde yarıya bölme iç tutarlığa sahip olduğu bulunmuştur. Orijinal çalışmaya uygun olarak, üç alt boyutun çaprazlanması ile sekiz anne bekçiliği alt türü oluşturulmuş ve bekçilik türlerinin görülme sıklıkları belirlenmiştir. Bulgular, ölçeğin güvenirliği ve geçerliğinin tatmin edici düzeyde olduğuna işaret etmektedir. Anne bekçiliği alt boyutları birtakım demografik özelliklere göre de incelenerek, tüm bulgular ilgili literatür ve gelecek çalışmalar açısından tartışılmıştır.

Anahtar kelimeler: Anne bekçiliği ölçeği, baba katılımı, geçerlik, güvenirlik

\begin{abstract}
In this study the reliability and validity of 42 items-Maternal Gatekeeping Scale-Mother Form (MGS-M), a scale developed to evaluate encoragement, discouragement and control behaviors of mothers on fathers, were examined for the Turkish adaptation. A total of 210 mothers with children aged 4-6 participated in the study. Confirmatory factor analyses revealed that MGS-M has a three-factor solution in accordance with the original scale. The correlation coefficients with the Father Involvement Scale, used to determine the criterion validity of the MGS-M, were in the expected direction and significant. The sub-dimensions of MGS-M were found to have acceptable intarnal consistency and split-half reliability. In accordance with the original study, eight maternal gatekeeping types were formed by the crossing of the three-factor and the prevalence of the types of maternal gatekeeping were determined. The findings indicate that the reliability and validity of the scale were satisfactory. Sub-dimensions of maternal gatekeeping were examined according to some demographic characteristics and all findings were discussed in terms of related literature and future studies.
\end{abstract}

Keywords: Maternal gatekeeping scale, father involvement, validity, reliability

Yazışma Adresi: Arş. Gör. Güleycan Akgöz Aktaş, Mersin Üniversitesi Çiftlikköy Kampüsü, Fen-Edebiyat Fakültesi, Psikoloji Bölümü, Mersin.

E-posta: glycnakgoz@gmail.com

Gönderim Tarihi: 29.03.2019

Kabul Tarihi: 31.01 .2020 
Sağlıklı bir ebeveyn çocuk ilişkisinin çocuğun duygusal, sosyal, bilişsel ihtiyaçlarının karşılanması ve olumlu geçirilen bir erken çocukluk dönemi ile ilişkili olduğu bilinmektedir (örn., Amato, 2002; Belsky, Youngblade, Rovine ve Volling, 1991; Bowlby, 1988). Aile yapısı içinde çocuğa birincil bakım verenin anne olduğu görülmekle birlikte, son yıllarda çocuğun anneden gördüğü ilgi, yakınlık ve bakım kadar babanın çocuk yetiştirme sürecindeki katkısının da çocuk üzerinde olumlu sonuçları olduğunu vurgulayan çalışmalar yapılmaktadır (Lamb, Pleck ve Levine, 1985; MacDonald, 2009, Tu, Chang ve Kao, 2014). Özellikle annelerin iş hayatında daha etkin rol almaya başlamaları; hem anneliğe hem de babalığa ilişkin geleneksel anlayışı değiştirmeye başlamış, babalara ilişkin değişkenlerin saptanmasını ve çocuk için etkilerinin incelenmesini önemli hale getirmiștir (Kulik ve Sadeh, 2015). Konuya yönelik araştırmalar; baba çocuk etkileşiminin çocuğun psikososyal ihtiyaçlarının karşılanması ve olumlu sosyal davranışlar kazanmasında rol oynadığını göstermenin yanı sıra; babanın çocuk bakımına yardımcı olması, çocuk için hazır bulunup ona ilgi göstermesi olarak tanımlanan baba katılımı$\mathrm{n} 1$ da çocuğun uyumunu etkileyen olumlu bir deneyim olarak görmektedir (Cox, Paley ve Harter, 2001; Downer, Campos, McWayne ve Gartner, 2008). Çok sayıda çalışmada baba katılımının çocukların bağlanma örüntüleri, arkadaşlık ilişkileri, iyi olma hali, duygusal gelişimleri, davranış problemleri ile ilişkili olduğu ortaya konmuştur (örn., Caldera, 2004; Dubowitz ve ark., 2001; Kennedy, Betts, Dunn, Sonuga-Barke ve Underwood, 2015). Bununla birlikte baba katılımında rol oynayan değişkenleri araştıran çalışmacılar; baba çocuk etkileşiminin babanın kendisinden ve çocuktan kaynaklanan özellikleri olduğu kadar, evlilik ilişkisi ve anne davranışlarının da baba çocuk etkileşimine yön verdiğini ortaya koymaktadır (Coley ve Morris, 2002; Paulson, Dauber ve Leiferman, 2011). Aile sistem kuramcıları aile içinde yaşanan bu karşılıklı ilişsileri yayılma etkisi olarak adlandırmakta (Cox, Paley ve Harter, 2001); benzer olarak, ekolojik yaklaşımla yürütülen çalışmalarda da aileye ait mikrosistemlerin birbirinden ayrı düşünülemeyeceği açıkça görülmektedir (Kulik ve Sadeh, 2015). Şimdiye kadarki araştırmalarda; evlilikte yaşanan çatışmaların, anneleri eşleri ile işbirliği yapmaktan alıkoyarak baba katılımını azaltabileceği (De Luccie, 1995); düşük evlilik uyumunun görüldüğü ailelerdeki çocuklarda saldırganlık gibi dışa yönelim problemlerine daha fazla rastlandığ 1 , bu çocukların çatışmanın yarattı̆̆ oldukları (Cummings, Goeke-Morey ve Papp, 2004) ve ebeveynler arasındaki ilişkinin bozularak çatışmanın arttığı evliliklerde baba çocuk etkileşiminin azaldığı rapor edilmiştir (Stevenson ve ark., 2014). Bu bilgiler 1şı̆̆ı̆ında baba çocuk ilişkisi incelenirken; annelerin, sözü geçen babalık davranışlarına verdikleri tepkiler açısından özel bir konumda olduğu görülmektedir.

Çocuk yetiştirme konusuna ilişkin değişen algılar ve sorumlulukların paylaşılması, babaların aile içinde daha çok görev üstlenmesi ve hem ev işlerine hem de çocuk bakımına daha çok katkı sağlamaya başlaması; annelerin babalık görevlerine ilişkin bakış açısını da etkilemekte ve değiştirmektedir. Öyle ki baba katılımına ilişkin oldukça kapsamlı bir derleme çalışmasında Uludağlı (2017); ebeveynlikleri eşleri tarafından destek gören babaların daha s1k baba katılımı sağladığını, aksine annelik görevlerinde güç kaybetmek istemeyen ve eşlerinin babalık görevlerinde tereddüt yaşayan annelerin ise baba katılımına olumsuz tepkiler verebildiklerini aktarmıştır. Dolayısıyla; annelerin baba katılımına olan etkisi, annenin baba katılımından nasıl ve ne yönde etkilendiğine ve farklılaşan babalık rolüne ilişkin algısına bağlı olarak değişmektedir. İlk olarak De Luccie (1995), bütüncül bir yaklaşımı savunarak, baba çocuk ilişkisinde annelerin rolünü ifade etmek için bekçilik (gatekeeping) kavramını kullanmıștır. 1999'da Allen ve Hawkins, kavramı yeniden düzenleyerek anne bekçiliği (maternal gatekeeping) olarak tanımlamıştır. Aynı zamanda ilk anne bekçiliği ölçeğini geliştiren Allen ve Hawkins’e (1999) göre anneler; ev işlerinde eşlerine nazaran daha çok sorumluluk aldıklarını düşünerek, annelik ve eşlik rolleriyle çevrelerinden onay alma isteği duyarak ve anne babalık görevlerine yönelik cinsiyet rolü ayrımlarına inanarak bekçilik yaparlar. Bu tür davranışlara maruz kalan babalar anneler tarafindan kısıtlanır, ev işlerini öğrenemez ve geri çekilirler (Dollahite ve Hawkins, 1997).

İlk bekçilik çalışmalarından farklı olarak bazı çalışmacılar (Fagan ve Bernett, 2003; Puhlman, 2013), anne bekçiliğinin yalnızca ev işleri ile sınırlandırılamayacağını göstermiştir. Örneğin Hauser (2012), küçük çocuklu ebeveynlerle yaptığı bir dizi görüşmeye dayalı niteliksel çalışmasında, kadınların ebeveynlik kararlarını ve çocuklarla ilgili işleri kontrol etmeyi üstlenerek bekçilik yaptıklarını bildirmiştir. Fagan ve Bernett ise; 2003 yılında yürüttükleri bir çalışmalarında annelerin ev işlerinin yanı sıra, babaların çocuklarıyla geçirdiği zamanla ilgili de kısıtlayıcı ve kontrolcü davrandıklarını gözlemlemişlerdir. Bu yönüyle anne bekçiliği kavramı 'babaların aile içindeki işlere katılımını engelleyen anne girişimleri' olmanın ötesinde 'baba çocuk etkileşimini sınırlayan anne davranışları' olarak ifade edilmeye başlanmıştır (Gaunt, 2008; Fagan ve Bernett, 2003).

Walker ve McGraw 2000'li y1llara kadar baba çocuk etkileşimini olumsuz etkileyen annelik davranışları olarak karşımıza çıkan anne bekçiliği kavramına yeni bir bakış açısı getirerek, annelik davranışlarının olumsuz sonuçları kadar kolaylaştırıcı etkileri de olabileceğine dikkat çekmişlerdir. Ardından gelen bazı çalışmalar araş- 
tırmacıların iddiasını destekler görünmektedir. Örneğin Roy ve Dyson (2005) mahkum babaların partnerlerine ilişkin algılarını inceledikleri niteliksel çalışmalarında; babaların \%74'ü, hapiste olmalarına rağmen partnerleri tarafından çocuklarla ilgili işler için cesaretlendirildiklerini belirtirken; \%26's1 partnerlerinin kendilerini hem cesaretlendirdiklerini hem engellediklerini rapor etmiştir. Aynı çalışmada yalnızca engellenme yaşayan babaların oranı ise $\% 48$ olarak sunulmuştur. Yine Sano, Richards ve Zvankovic (2008) yürüttükleri niteliksel çalışmalarında, babaların eski eşlerinin bekçilik yaptığ 1 iddialarına karşın annelerin düzenli ve aktif bir baba-çocuk ilişkisini arzuladıklarını rapor etmişlerdir. Annelerin baba-çocuk etkileşimini destekleme isteklerine rağmen, babadan beklenen ebeveynlik rollerini yerine getirmediğini algıladıklarında eski eşlerine karşı hayal kırıklığı ve güvensizlik yaşadıkları; ancak annelerin babalar tarafından bekçilik olarak yorumlanabilecek davranışlarının genellikle baba katılımını engelleme amacı taşımadığını, daha çok kabul edilebilir baba davranışlarına dair taleplerini babalara iletme amaçlı olduğunu belirtmişlerdir. Öyle ki Seery ve Crowley (2000) çocuklarıyla yaşayan annelerin eşlerinden ayrıldıktan sonra bile baba-çocuk ilişkilerini desteklemeye çalıştıklarını bulmuştur. Böylelikle anne bekçiliği, 'baba davranışlarını düzenlemek amacı ile anneler tarafindan gösterilen eleştirel ya da onaylayıcı davranışlar' olarak görülmeye başlanmıştır (Schoppe-Sullivan, Brown, Cannon, Mangelsdorf ve Sokolowski, 2008). Puhlman ve Pasley (2013) söz konusu kavram değişikliğini aile sistem teorisi ve feminist bakış açısının görüşleriyle birlikte değerlendirip açıklamaya çalışmışlardır. Bilindiği gibi aile sistem teorisi; roller, kurallar, sınırlar, denge, geri bildirim gibi kavramları kullanır ve aile içindeki yapıyı birbirine bağlı etkileşim halindeki dinamikler olarak görüp anlamaya çalışır (Fagan ve Barnett, 2003). Bu bağlamda, aile içinde gelişen herhangi bir olay, aile dinamiğine bağl1 olarak, bazı ailelerde çatışmaya yol açarken, bazı ailelerde uygun ve olumlu sonuçlar verebilmektedir (White ve Klein, 2008). Feminist bakış açısı ise, kadın ve erkeğin aile içindeki davranış ve rol kalıplarındaki güç dengesizliklerinin karşılıklı etkileşim halinde bulunarak nasıl geliştiğini açıklamaktadır. Buradan hareketle Puhlman ve Pasley (2013), anne bekçiliğini; 'eşlerin karşılıklı etkileşimiyle gelişen ve annenin baba üzerinde kontrollü, kolaylaştırıcı ya da sınırlayıcı yöntemler kullanarak, babanın çocuk bakımı uygulamalarını ve çocukla ilişkisini düzenli, uygun ve tutarlı duruma getirme davranışları' olarak tanımlamaktadır. Anne bekçiliğine ilişkin yeni modelde araştırmacılar, anne bekçiliğini oluşturan üç boyut tanımlamışlardır: kontrol, teşvik ve engel. 'Kontrol' boyutu, özellikle aile içi karar alma süreçlerinde kullanılır ve karar alırken sözü geçen kişinin kontrol meka- nizmasını güçlü kılar; ancak annenin kontrol boyutunda yüksek değer alması, onun baba çocuk ilişsisine olumlu ya da olumsuz etkide bulunduğunu ifade etmez. Bir diğer deyişle, karar alma durumlarında öncü ve baba üzerinde çok kontrol sağlayan bir annenin, baba katılımını düşürüp düşürmeyeceği, diğer boyutların varlığı ve kullanımı ile açıklanabilir. 'Teşvik' boyutunda anne, babayı destekleyici davranışlarda bulunur. Baba katılımına geniş alan sağlar ve baba çocuk etkileşimini kolaylaştırır; ancak tıpkı kontrol boyutundaki gibi, teşvik edici olmayan bir anne, baba katılımını gereksiz bulan ve babanın katılımından hoşlanmayan bir anne gibi yorumlanamaz. Bunun yerine, babanın çocukla etkileşimini onaylamak ya da babaya olumlu geri bildirimler vererek onu desteklemekle ilgilenmediği düşünülebilir. 'Engel' boyutunda ise anne, babaya sınırlar koyarak baba çocuk ilişkisini ketler ve kısıtlar. Babanın davranışlarını desteklemez ve onunla çatışır. Bu boyutta annenin engelleyici tavırlarını göstermesi açıkça (davranıştan hoşlanmadığını direkt söylemesi gibi) olabileceği gibi örtük biçimde (babanın çocukla etkileşimi sırasında, bu durumdan hoşlanmad1ğını belirten bir göz hareketi yapması gibi) de olabilir (Puhlman ve Pasley, 2013). Araştırmacılar, bu üç boyutun kullanılma şekline göre toplamda sekiz tür anne bekçiliği tanımlamışlardır. Bu türler kararlı ve kararsız anneler olmak üzere iki kategoride incelenmektedir. $\mathrm{Ka}$ rarl anneler (polarized mothers), babalara karşı net ve açık davranışlar gösterirken, yüksek teşvik düşük engel ya da yüksek engel düşük teşvik düzeyinde bulunurlar. $\mathrm{Bu}$ sınıflandırmadaki annelerin kontrol düzeyi ise tercih ettikleri davranışların yoğunluğunu yansıtır. Çok kontrollü bir anne, baba üzerinde gösterdiği olumlu ya da olumsuz davranışları artırır. Kararlı annelikteki bekçilik türlerinden biri olan geleneksel sınır koyucu bekçilikte (traditional gate blocker) anne; yüksek kontrol, düşük teşvik ve yüksek engel durumunda bulunur. Baba kat1lımına engel koyar, babaya nasıl ve ne zaman katılım sağlayacağını söyler, baba hakkında olumsuz konuşur ve eşler arasında incitici bir diyalog hakimdir. Diğer bir tür olan pasif engelleyici (passive gate snubber) anneler, çocuğa babası hakkında olumsuz yorumlar yapar, babanın yaptığ1 şeyleri yeniden kendisi yapar ve düzeltir, baba ve çocuğun birlikte geçirdiği zamanı 'kazara' böler. Pasif engelleyici bekçilikte; düşük kontrollü, az teşvik eden ancak yüksek engel düzeyinde bulunan annelerden bahsedilmektedir. Kolaylaştırıcı bekçi (facilitative gate opener) anneler; yüksek kontrol, yüksek teşvik ve düşük engel boyutlarında bulunarak; baba ve çocuğun geçireceği zamanı programlar, babaya ilişkin günleri (doğum günü gibi) kutlar, baba ve çocuk oyununa doğrudan müdahale eder, babadan güçlü olduğunu gösteren davranışlar sergiler. Pasif kolaylaştırıcı bekçi (passive gate welcomer) anneler ise, baba hakkında olumlu konuşur, babanın 
ebeveynliğini destekler, aile dışı aktivitelerle ilgilidir ve evde lider olma konusunda denge hakimdir. Pasif kolaylaştırıcı bekçi annelerin düşük kontrol, yüksek teşvik ve düşük engel sağladığı belirtilmektedir. Kararsız anneler (ambivalent mothers) ise, farklı ve tutarsız davranışları ile kafa karıştırıcıdır; çünkü teşvik ve engel boyutlarında aynı seviyede bulunurlar. Baba katılımını çok önemseyebildikleri gibi, bu durumla ilgilenmeyebilirler (Puhlman ve Pasley, 2013). Kararsız anneliğin türlerinden biri olan tutarsız yönetici (confused gate manager) anneler, hem olumlu hem olumsuz davranışları iç içe sergiler, duruma göre davranışlarını değiştirir, aile içi iletişimi yönetir. Tutarsız yönetici bekçilikten kasıt, annenin üç boyutta da yüksek seviyelerde bulunmasıdır. Duyarsız yönetici (apathetic gate manager) anneler, aile içinde lider olmak ister, çocukları ile ilgili önemli kararları tek başlarına alırlar, babaya karşı tutarsız davranırlar. Duyarsız yönetici bir anne yüksek kontrol, düşük teşvik ve düşük engel seviyelerinde bulunur. Başına buyruk yönetici bekçilikte (opinionated gate manager) anneler, babalara hem iltifat eder hem de onlarla çatışırlar, kaçınmacı biçimde iletişim kurmayı tercih ederler, baba katılımı ile ilgisizdirler. Başına buyruk yönetici bekçilik gösteren anneler düşük kontrol, yüksek teşvik ve yüksek engel gösterenler şeklinde tanımlanmaktadır. Görünmez bekçi (invisible gate ignorer) anneler ise, üç boyutta da düşük seviyelerde bulunarak, aile iletişimi ve yönetiminden çok uzaktırlar, çelişkili davranışlarda bulunurlar, babalar aile içindeki yöneticilerdir (Puhlman ve Pasley, 2013).

Literatürde anne bekçiliğinin birtakım ebeveyn ve çocuk özellikleri açısından incelendiği çalışmalar olduğu görülmektedir. Örneğin Gaunt (2008); düşük benlik sayg1sı, kadınsı cinsiyet rollerine aşırı bağlı olma, annelik rollerini abartma, çevresinden iyi anne olduğuna ilişkin ipuçları yakalamak isteme, düşük eğitim düzeyine sahip olma, anksiyete ve depresyon düzeyinin yüksek olmas1, mükemmeliyetçi kişilik yapısı ve çalışma saatlerinin az olması gibi özelliklere sahip annelerin bekçilik davranışlarının daha olumsuz olduğunu kaydetmiştir. Yine aynı çalışmasında Gaunt (2008); çocukların yaşı ile anne bekçiliği arasında bir ilişki bulamadığını bildirmiştir. Ardından Kulik ve Tsoref (2010), eğitim düzeyi yüksek olan annelerin daha az bekçilik gösterdiklerini belirtmiş; Tu, Chang ve Kao (2014) da annenin çalışma saatleri ile anne bekçiliği arasında negatif yönde bir ilişki saptamışlardır. Puhlman ve Pasley (2013) ise; gelecek çalışmalarda yaş, cinsiyet, mizaç gibi çocuk özelliklerinin anne bekçiliği ile ilişkisinin incelenmesinin gerekliliğini vurgulamakla birlikte annelerin bekçilik davranışlarının özellikle çocukların yaşlarına göre farklılaşabileceğine dair beklentilerini bildirmişlerdir. Ülkemizde anne bekçiliğine ilişkin yapılan ilk çalışmada Karabulut ve Şendil (2017), anne bekçiliğinin çocuğun cinsiyeti, ailenin ekonomik durumu ve ebeveynlerin çalışma biçimleri ile ilişkisi olmadığını bulmuşlar; yine aynı çalışmada babaların eğitim düzeyi arttıkça anne bekçiliğine maruz kalma düzeylerinin azaldığını raporlamışlardır.

Tüm bu çalışmalar incelendiğinde, anne bekçiliği kavramına ilişskin literatürün son yirmi yıla dayandığı ve geliştirilmeye açık bir alan olduğu görülmektedir. Ülkemizde ise anne bekçiliğine ilişkin tek ölçme aracı olan Anne Bekçiliği Ölçeği (ABÖ), 2017 yılında Karabulut ve Şendil tarafından uyarlanarak dilimize kazandırılmıştır. Araştırmacılar söz konusu uyarlama çalışmasında, Fagan ve Bernett'in (2003) annelerin baba çocuk etkileşimini kısıtlayan davranışlarını değerlendiren ve annelerin öz bildirimine dayalı Anne Bekçiliği Ölçeği'ni uyarlama aşamasında bilgi kaynağı olarak babalara başvurmuşlardır. Bir başka ifadeyle annenin bekçilik davranışlarını orijinal ölçekte olduğu gibi anneden değil, babanın algısına dayandırarak değerlendirmişlerdir. Mevcut çalışmanın temel amacı ise, Puhlman ve Pasley'in (2017) hem olumlu hem olumsuz özellikleri içinde barındıran Anne Bekçiliği Ölçeği'nin dilimize uyarlanarak psikometrik özelliklerinin belirlenmesidir. Çalışmada literatürde ağırlıklı olarak anne beyanına dayanan bekçilik çalışmalarına rastlanmasına rağmen (Allen ve Hawkins, 1999; Fagan ve Barnett, 2003; Gaunt ve Pinho, 2018), Türkçe literatürde anne bildirimine dayanan bir bekçilik ölçeğinin bulunmaması göz önüne alınarak, ölçeğin anne bildirimine dayanan formu kullanılmış, geçerlik güvenirlik hesaplamaları 4-6 yaş arası çocuğa sahip annelerin bulunduğu bir örneklem üzerinden yapılmıştır. Bununla birlikte anne bekçiliğinin birtakım demografik özelliklerle ilişkisi de incelenmiştir. Ölçeğin uyarlanması ile özellikle erken dönem ebeveyn çocuk etkileşimini inceleyen çalışmalara katkı sağlanacağı düşünülmektedir.

\section{Yöntem}

\section{Örneklem}

$\mathrm{Bu}$ araştırmanın örneklemini, Mersin'de okul öncesi kurumlarda eğitim öğretim görmekte olan 4-6 yaş arası çocuğa sahip anne ve babalar oluşturmuştur. Çalışma için uygun örneklem büyüklüğü belirlenirken, Puhlman'ın (2013) sunduğu kriterlere dikkat edilmiştir. Araştırmacı yürüttüğü güç analizinde gerekli olan örneklem sayısını, anne bekçiliğine ilişkin geçmiş literatürdeki 1lımlı etkiyi göz önüne alarak .5 etki büyüklüğü ve $\% 90$ şansla 140 katılımcı olarak hesaplamıştır. Bununla birlikte Kline (2011) doğrulayıcı faktör analizi için gerekli olan minimum örneklem sayısın1 200 olarak bildirmiştir. Söz konusu araştırmalardan hareketle, mevcut çalışmanın 210 kişilik örneklem büyüklüğünün (210 anne, 210 baba), yürütülen analizler için uygun olduğu düşünülmektedir. Çalışmada dışlama ölçütü olarak, boşanmış 
Tablo 1. Katılımcıların Özelliklerine İlişskin Ayrıntılar

\begin{tabular}{|c|c|c|}
\hline & Ort. & $S$. \\
\hline \multicolumn{3}{|l|}{ YAŞ } \\
\hline Anne & 34.8 & 4.8 \\
\hline Baba & 38.8 & 6.1 \\
\hline Çocuk & 5.25 & 0.7 \\
\hline \multicolumn{3}{|l|}{ ÇALIŞMA SAATİ } \\
\hline Anne & 4.3 & 4.4 \\
\hline Baba & 8.94 & 3.8 \\
\hline \multirow[t]{2}{*}{ EVLİLİK SÜRESİ (yıl olarak) } & 9.85 & 4.1 \\
\hline & $n$ & $\%$ \\
\hline \multicolumn{3}{|l|}{ ANNE EĞİTİM DÜZEYİ } \\
\hline İlkokul-Ortaokul & 37 & 17.6 \\
\hline Lise & 71 & 33.8 \\
\hline Yüksekokul-Üniversite & 88 & 41.9 \\
\hline Lisansüstü & 14 & 6.7 \\
\hline \multicolumn{3}{|l|}{ BABA EĞİTIMM DÜZEYİ } \\
\hline İlkokul-Ortaokul & 47 & 22.9 \\
\hline Lise & 62 & 28.1 \\
\hline Yüksekokul-Üniversite & 85 & 39.0 \\
\hline Lisansüstü & 16 & 10.0 \\
\hline
\end{tabular}

olmak ve çocuk sahibi olmamak koşulu kullanılmıştır. Katılımcıların çocuklarının 104'ü (\%49.5) kız, 106's1 (\%50.5) erkektir; bununla birlikte 39'u (\%18.6) 4, 80'i (\%38.1) 5 ve 91'i (\%43.2) 6 yaş grubundadır. Katılımcıların özelliklerine ilişkin ayrıntılar Tablo 1'de sunulmuştur.

\section{Veri Toplama Araçları}

Demografik Bilgi Formu: Çocuk sayısı, çocuğun yaşı, cinsiyeti ve ebeveynlere ilişkin yaş, çalışma saati, eğitim düzeyi, evlilik süresi, çocuğun doğum sırası gibi bilgilerin toplanması için araştırmacı tarafından anne ve babalar için ayrı ayrı oluşturulmuş Demografik Bilgi Formu kullanılmıştır.

Baba Katılım Ölçeği (BAKÖ): Sımsıkı ve Şendil (2014) tarafından 3-6 yaş aralığındaki çocukların baba katılımını değerlendirmek amacıyla geliştirilmiş 37 maddelik ölçek, 5'li Likert tipinde babaların katılımlarına ilişkin öz bildirimlerine dayanan bir ölçme aracıdır. Ölçek, babanın çocukla gerçekleştirdiği serbest zaman etkinliklerini ve oyunları ifade eden 'keyfi meşguliyet' (KM - 17 madde, örneğin "Çocuğumla birlikte spor yaparım.”), çocuğa duyarlı davranıp sözel ve fiziksel sevgi göstermeyi ifade eden 'ilgi ve yakınlık' (İY - 12 madde, örneğin "Çocuğumun saçlarını tararım.") ve çocuğun günlük ihtiyaç ve bakımında yer almayı ifade eden 'temel bakım' (TB - 8 madde, örneğin "Çocuğumun tırnaklarını keserim.”) alt boyutlarından oluşmaktadır. Alt boyutların Cronbach Alfa iç tutarlık katsayıları keyfi meşguliyet için .89, ilgi ve yakınlık için .85, temel bakım için .83 ve ölçeğin tüm toplam maddeleri için .92 olarak verilmiştir. Ölçekten alınan puanlar 37 ile 185 arasında değişmektedir ve yüksek puan almak baba katılımının yüksek olduğuna işaret etmektedir. Mevcut çalışma kapsamında ölçeğin Cronbach Alfa iç tutarlık katsayıları KM için .87, İY için .79, TB için .82 ve BAKÖ tüm toplam maddeleri için .90 bulunmuştur.

Anne Bekçiliği Ölçeği: Puhlman ve Pasley (2017) tarafından annelerin babalar üzerindeki teşvik edici, kontrolcü ve kısıtlayıcı davranışlarının değerlendirilmesi amacıyla geliştirilen Anne Bekçiliği Ölçeği (Maternal Gatekeeping Scale-MGS), araştırmacılar tarafından önceki yıllarda yazılmış ölçek maddeleri düzenlenerek oluşturulmuş 42 maddeden oluşmaktadır. Puhlman ve Pasley (2017) yürüttükleri geçerlik ve güvenirlik analizleri sonrası anne ve babalar için ayrı ayrı oluşturulmuş 15 
maddelik, Likert (0-Asla, 1-Çok Nadir, 2-Nadiren, 3-Bazen, 4- Çoğu Zaman, 5- Her Zaman) tipinde ve 3-7 yaş aralığında çocuğu olan ebeveynler için kullanılabilecek bir ölçek geliştirmişlerdir. Ölçek, aile içinde karar alma mekanizmalarının gücünü ifade eden kontrol (örneğin "Eşimin çocukla geçirdiği zamanı denetlerim"), babayı destekleyici davranışlara ilişkin maddeleri kapsayan teşvik (örneğin "Çocukla baş başa vakit geçirmesi için eşimi teşvik ederim.") ve babayı kısıtlayıp ona engeller koyan anne davranışlarını tanımlayan maddeleri içeren engel (örneğin "Eşimin babalığılla ilgili beğenmediğim şeyleri başkalarına anlatırım.") boyutlarından oluşmaktadır. Araştırmacılar ilk kez 2013 yılında yürüttükleri çalışmada; anneleri 2 kategoride (kararlı anneler ve kararsız anneler) 8 alt türe ayırarak, bekçilik davranışları açısından sınıflandırmışlardır: geleneksel sınır koyucu bekçilik (traditional gate blocker), pasif engelleyici bekçilik (passive gate snubber), kolaylaştırıcı bekçilik (facilitative gate opener), pasif kolaylaştırıcı bekçilik (passive gate welcomer); tutarsız yönetici bekçilik (confused gate manager), duyarsız yönetici bekçilik (apathetic gate manager), başına buyruk yönetici bekçilik (opinionated gate manager) ve gözlenmeyen bekçilik (invisible gate ignorer). Orijinalinde, ölçeğin Cronbach Alfa analizi tüm alt boyutlara ayrı ayrı yapılmış ve anne formu için .72 ile .82 arasında rapor edilmiştir.

\section{İşlem}

Anne Bekçiliği Ölçeği Anne Formu'nun (ABÖ-A) Türkçeye uyarlama çalışması için ölçeği geliştiren yazarlardan alınan onaydan sonra çeviri aşamasına geçilmiştir. Bu süreçte ölçek maddeleri; üç yargıcı tarafından çeviri-geri çeviri yöntemiyle Türkçeye çevrilmiş, ardından Mersin Üniversitesi Sosyal ve Beşeri Bilimler Etik Kurulu, Valilik ve İl Milli Eğitim Müdürlüğü'nden gerekli etik izinler sağlanarak veri toplama aşamasına geçilmiştir. Anne ve babalara ait ölçekler doldurulmak üzere, içlerine bilgilendirilmiş onam formu dahil edilmiş ayrı ayrı kapalı zarflar içerisinde öğretmenler tarafından evlere gönderilmiştir. Formlar gönderilmeden önce tüm öğretmenler anne-baba-çocuk eşlemesini yapmış; ancak araştırmacıya bildirmemiştir. Eşlemenin kontrolü ve babaların yanıtlaması beklenen Baba Katılımı Ölçeği'nde tek bir çocuğa ilişkin bilgilerin alınması için, baba formunda ayrıca ölçeğin kaçıncı çocuk için doldurulduğu bilgisi istenmiştir. Doldurulan ölçekler benzer şekilde ebeveynler tarafindan öğretmenlere teslim edilmiş ve araştırmacı tarafindan öğretmenden teslim alınmış̧ır. Toplamda elde edilen 265 kişilik veri seti, araştırmanın ana konusu olan ölçek sorularının \%80'den fazlasını cevaplamamış olan ve çalışmaya katılmayı reddeden ebeveynler analize dahil edilmediğinde, 210 anne ve babanın bilgileri ile son halini almıştır.
Verilerin analizi; ABÖ-A'nın geçerlik güvenirlik çalı̧̧malarının yanı sıra, ölçeğin bazı demografik özelliklerle ilişkisini ve orijinalindekine uygun olarak anne bekçiliği alt türlerinin oluşturulmasını içermektedir. Ölçeğin yapı geçerliği çalışması için doğrulayıcı faktör analizi, kriter geçerliği için ise benzer ölçekle korelasyon analizleri yapılmıştır. Iç tutarlık hesaplamalarında Cronbach Alfa katsayısının yanı sıra ölçekleri yarıya bölme yöntemi kullanılarak Guttmann güvenirlik katsayısı rapor edilmiştir. Verilerin betimleyici analizleri, güvenirlik katsayılarının hesaplanması ve korelasyon analizleri için SPSS 20 programı, doğrulayıcı faktör analizi için ise R paket programı kullanılmışır.

\section{Bulgular}

\section{Anne Bekçiliğ̈i Ölçeğinin Geçerlik Analizleri}

Anne Bekçiliği Ölçeği Anne Formu'nun daha önceden araştırmacılar tarafindan (Puhlman ve Pasley, 2017) belirlenmiş faktöriyel yapısını test etmek amacıyla CRAN-R yazılımı Lavaan paket programı kullanılarak doğrulayıcı faktör analizi (DFA) yürütülmüștür. Puhlman (2013), oldukça homojen bir örneklemle çalıştılarını bildirdiğinden, her yeni örneklemde maddelerin işlerliğinin analiz edilmesinin faydalı olacağı düşünülmüşsür. Analizler, Puhlman'ın (2013) ölçeğe son halini vermeden önce oluşturduğu toplam 42 madde üzerinden yapılmış, madde faktör yüklerinin .07 ile .68 arasında değiştiği görülmüştür. Bununla beraber bazı maddelerin normal dağılıma uymadığı $(3,10,20,25,27)$, bazılarının ise madde yüklerinin çok düşük olduğu $(2,5,12,13,30,36,37,40)$ ve çıkarıldıklarında güvenirlik katsayısının yükseldiği tespit edilmiştir. DFA, ilgili maddeler çıkarıldığında kalan 29 madde ile (teşvik 12, engel 9 ve kontrol 8 madde) yinelendiğinde analize ilişkin uyum indekslerinin kabul edilebilir sınırlar içinde olduğu görülmüştür $(\chi 2$ [374, $\mathrm{N}=210]=604.592, \chi 2 / s d=1.61$, RMSEA $=.052(\% 90$ güven aralığı: $.047, .057), \mathrm{GFI}=.89, \mathrm{AGFI}=.87, \mathrm{CFI}$ $=.86$ ). Analizde alt boyutları temsil eden gizil bileşenler arasında engel ile kontrol boyutları için .75, engel ile teşvik boyutları için -.53 ve kontrol ile teşvik boyutları için -.10 oranında yapısal bir ilişki bulunmuştur. Modele ilişkin faktör yükleri ve madde-toplam madde korelasyonları Tablo 2'de görülmektedir.

\section{Kriter Geçerliği}

Anne Bekçiliği Ölçeği Anne Formu'nun kriter geçerliğini incelemek üzere, üç alt boyuttan oluşan Baba Katılım Ölçeği (BAKÖ) ile arasındaki korelasyon değerleri hesaplanmıştır. Bulgular; BAKÖ toplam puanı ile $A B O ̈-A$ teşvik alt boyutu arasında pozitif yönlü bir ilişkiye $(r=.20, p<.05)$, engel alt boyutu ile negatif yönlü bir iliş̧iye $(\mathrm{r}=-.32, \mathrm{p}<.001)$ ve kontrol alt boyutu ile 
negatif yönlü bir ilişkiye $(r=-.14, p<.05)$ işaret etmektedir. BAKÖ alt boyutları ve ABÖ-A alt boyutları arasında kriter geçerliğine ilişkin korelasyon katsayıları ve ölçeklere ilişkin ortalama, standart sapma, ranj değerleri Tablo 3'te görülmektedir.

\section{Anne Bekçiliği Ölçeği'nin Güvenirlik Analizleri}

Anne Bekçiliği Ölçeği Anne Formu'nun alt boyutlarının iç tutarlıklarının incelenmesi amacıyla Cronbach Alfa değerleri hesaplanmış; teşvik boyutu için .81, engel boyutu için .66 ve kontrol boyutu için .74 bulunmuştur. Engel boyutunun güvenirlik katsayısı görece düşük hesaplanmış olmakla birlikte, kabul edilebilir sınırlar içinde değerlendirilmektedir.

Anne Bekçiliği Ölçeği Anne Formu'nun alt boyutlarının Cronbach Alfa güvenirlik katsayılarının yanı sıra, ölçeğe verilen cevapların tesadüfi hatalardan arınık olup olmadığını anlamak üzere, yarıya bölme yöntemi kullanılmıştır. Buna göre her bir alt boyut eş iki yarıya ayrılarak katılımcıların yarılardan aldıkları puanlar arasındaki korelasyon değerleri hesaplanmıştır. Sonuçlar Guttman güvenirlik katsayılarının teşvik boyutu için .79, engel boyutu için .60 ve kontrol boyutu için .74 olduğunu göstermektedir.

\section{Anne Bekçiliğinin Demografik Özelliklerle İlişkisi}

Anne bekçiliği bazı demografik özelliklere göre de incelenmiştir. Anne bekçiliği alt boyutları ile ebeveynlerin yaşı arasındaki ilişki Pearson Momentler Çarpımı Korelasyon Değişmezlik Katsayıları ile incelenmiştir. Buna göre annelerin yaşı ile anne bekçiliği teşvik, engel ve kontrol alt boyutları arasında anlamlı bir ilişki olmadiğ1 görülmüştür (sırasıyla $\mathrm{r}=.07, \mathrm{p}>.05 ; \mathrm{r}=-.01, \mathrm{p}>$ $.05 ; \mathrm{r}=-.06, \mathrm{p}>.05)$. Benzer şekilde bekçiliğin teşvik, engel ve kontrol boyutları ile babaların yaşı arasında da anlamlı bir ilişki yoktur (sırasıyla $\mathrm{r}=-.01, \mathrm{p}>.05 ; \mathrm{r}=$ $-.01, \mathrm{p}>.05 ; \mathrm{r}=-.03, \mathrm{p}>.05)$.

ABÖ Anne Formu'nun alt boyutlarının çocuk cinsiyetine göre farklılık gösterip göstermediğini saptayabilmek için bağımsız örneklemler için t testi uygulanmıştır. Sonuçlara göre; teşvik $[\mathrm{t}(208)=.850, \mathrm{p}>.05]$ ve engel $[\mathrm{t}(208)=.178, \mathrm{p}>.05]$ düzeylerinin çocuk cinsiyetine göre değişmediği görülmüştür. Ancak annelerin kontrol [t(208) $=.192, \mathrm{p}<.05]$ düzeyleri k1z çocukları olduğunda daha yüksek olmaktadır.

Anne bekçiliğinin ebeveynlerin eğitim düzeyine (ilkokul-ortaokul, lise, yüksekokul-üniversite, lisansüstü) göre değişip değişmediğine anne bekçiliği (3) x eğitim düzeyi (4) olmak üzere çok değişkenli varyans analizi (MANOVA) ile bakılmıştır. Sonuçlar; teşvik $[(F(3,205)=.70, p>.05]$ engel $[(F(3,205)=.01, p>$ $.05]$ ve kontrol $[(\mathrm{F}(3,205)=.58, \mathrm{p}>.05]$ boyutlarının anne eğitim düzeyine göre değişmediğini göstermek- tedir. Benzer şekilde teşvik $[(\mathrm{F}(3,205)=.80, \mathrm{p}>.05]$, engel $[(F(3,205)=.64, p>.05]$ ve kontrol $[(F(3,205)=$ $1.18, \mathrm{p}>.05]$ düzeyleri babaların eğitim düzeyine göre de farklılaşmamaktadır.

Anne bekçiliğinin evlilik süresi ve çocuk sayısı ile ilişkisi Pearson Momentler Çarpımı Korelasyon Değişmezlik Katsayıları ile incelenmiştir. Buna göre ebeveynlerin evlilik süreleri ile annelerin teşvik, engel ve kontrol düzeyleri arasında anlamlı bir ilişki görülmemektedir (sirasiyla $\mathrm{r}=-.02, \mathrm{p}>.05 ; \mathrm{r}=-.03, \mathrm{p}>.05 ; \mathrm{r}=-.09, \mathrm{p}>$ $.05)$. Çocuk sayısının annelerin engel ve kontrol düzeyleri ile ilișkisi olmadığ 1 görülürken (sırasıyla $r=-.05, p$ $>.05 ; \mathrm{r}=-.02, \mathrm{p}>.05$ ), teşvik düzeyleri ile pozitif yönde düşük düzeyde anlamlı bir ilişki olduğu bulunmuştur ( $\mathrm{r}=$ $.16, \mathrm{p}<.05)$. Bir diğer deyişle; çocuk sayısı arttıkça annelerin teşvik edici bekçilik davranışları da artmaktadır.

Anne bekçiliğinin ebeveynlerin çalışma saatleri ile ilişkisi de Pearson Momentler Çarpımı Korelasyon Değişmezlik Katsayıları ile incelenmiştir. Sonuçlar, annelerin çalışma saatleri ile engel ve kontrol düzeyleri arasında bir ilişki olmadığını (sırasıyla $r=-.04, \mathrm{p}>$ $.05 ; \mathrm{r}=-.08, \mathrm{p}>0.5)$; ancak teşvik düzeyleri ile pozitif yönde anlamlı bir ilişki olduğunu göstermiştir $(r=.12, p$ $<$.05). Çalışma saati yüksek olan anneler babaları daha çok teşvik etmektedir. Paralel olarak babaların çalışma saatleri ile annelerin engel ve kontrol düzeyleri arasında anlamlı bir ilişki bulunmazken (sırasıyla $\mathrm{r}=-.09, \mathrm{p}>.05$; $\mathrm{r}=-.02, \mathrm{p}>0.5)$; annelerin teşvik düzeyi ile babaların çalışma saatleri arasında pozitif yönde anlamlı bir ilişki görülmüştür $(r=.15, p<0.5)$. Çalışma saati artan babalar, çocukları ile ilgili işlerde eşleri tarafından daha çok teşvik edilmektedir.

\section{Anne Bekçiliğinin Sınıflandırılması}

Puhlman ve Pasley'in 2013'teki çalışmalarında olduğu gibi anne bekçiliği davranışları 3 alt boyutun çaprazlanması yoluyla 8 alt türde sınıflandırılmış ve frekans değerleri hesaplanmıştır. Anne bekçiliği türlerinin görülme sıklığının \%19,5 ile kolaylaştırıcı bekçilik, \%19 ile geleneksel sınır koyucu bekçilik ve tutarsız bekçilik, $\% 10$ ile gözlenmeyen bekçilik, \%9,5 ile pasif sınır koyucu bekçilik, \%9 ile pasif kolaylaştırıcı bekçilik, \%7,1 ile başına buyruk bekçilik ve son olarak \%6,7 ile duyarsız bekçilik olduğu görülmüştür. Puhlman ve Pasley (2013) tarafından babalar üzerinde en olumlu annelik davranışları olarak değerlendirilen kolaylaştırıcı bekçiliğin, 8 tür anne bekçiliği arasında altıncı sırada ve en olumsuz annelik davranışları olarak görülen geleneksel sınır koyucu bekçiliğin ikinci sırada yer aldığ 1 bulunmuştur. 
Tablo 2. Anne Bekçiliği Ölçeği'nin Faktör Yapısı

\begin{tabular}{|c|c|c|c|c|}
\hline Maddeler & $\begin{array}{l}\text { Faktör } \\
\quad 1\end{array}$ & $\begin{array}{l}\text { Faktör } \\
2\end{array}$ & $\begin{array}{l}\text { Faktör } \\
3\end{array}$ & $\begin{array}{l}\text { Madde-Toplam Madde } \\
\text { Korelasyonları }\end{array}$ \\
\hline $\begin{array}{l}\text { 33. Eşime "Çocuklar konusunda iyisin.", "Teşekkür ederim.", "Bu } \\
\text { ailede olduğun için mutluyum." gibi olumlu şeyler söylerim. }\end{array}$ & .68 & & & $.67 * *$ \\
\hline 9. Eşimin babalığını överim. & .67 & & & $.63 * *$ \\
\hline 35. Çocuğa eşim hakkında olumlu şeyler söylerim. & .61 & & & $.61 * *$ \\
\hline 1. Eşimin çocukla oyun oynama tarzını desteklerim. & .58 & & & $.55 * *$ \\
\hline 14. Çocukla ilgili bir zorluk yaşarsam eşimden yardım isterim. & .54 & & & $.51 * *$ \\
\hline 7. Çocukla kurduğu iletişim hakkında eşime olumlu şeyler söylerim. & .49 & & & $.52 * *$ \\
\hline 18. Eşimin anne babalık görevlerini katılma çabasını desteklerim. & .49 & & & $.51 * *$ \\
\hline 23. Eşime anne babalık hakkındaki fikirlerini sorarım. & .46 & & & $.53 * *$ \\
\hline $\begin{array}{l}\text { 26. Bir anne babalık görevini tamamlaması için eşimi desteklerim } \\
\text { (örneğin besleme, temizleme, eğitme gibi). }\end{array}$ & .46 & & & $.54 * *$ \\
\hline 22. Çocuğumu babasından yardım istemesi için teşvik ederim. & .45 & & & $.48 * *$ \\
\hline $\begin{array}{l}\text { 16. Eşim ve çocuğumun birlikte aktiviteler yapmaları için onlara ön } \\
\text { ayak olurum. }\end{array}$ & .42 & & & $.48 * *$ \\
\hline $\begin{array}{l}\text { 39. Çocuğumla birlikte eşim için (doğum günü, babalar günü, } \\
\text { başarılarını kutlama gibi) kutlama etkinlikleri düzenlerim. }\end{array}$ & .40 & & & $.46^{* *}$ \\
\hline 5. Eşim çocukla ilgilenebildiği için evden çıkabilirim. & .27 & & & $.15^{*}$ \\
\hline 12. Çocukla baş başa vakit geçirmesi için eşimi teşvik ederim. & .25 & & & $.17^{*}$ \\
\hline $\begin{array}{l}\text { 27. Çocuğun bakıma ihtiyacı olduğunu eşime hissettiririm (ipucu } \\
\text { veririm). }\end{array}$ & -.21 & & & .11 \\
\hline 17. Eşimin babalığını eleştiririm. & & .50 & & $.55^{* *}$ \\
\hline 28. Çocuğun önünde eşimle tartışırım. & & .47 & & $.49 * *$ \\
\hline $\begin{array}{l}\text { 11. Eşimin babalığıyla ilgili beğenmediğim şeyleri başkalarına } \\
\text { anlatırım. }\end{array}$ & & .46 & & $.55^{* *}$ \\
\hline 21. Eşimle karşılıklı konuşmadan çocukla ilgili kararlar alırım. & & .44 & & $.57 * *$ \\
\hline $\begin{array}{l}\text { 29. Çocukla etkileşimde olduğu sırada memnuniyetsizliğimi göstermek } \\
\text { için eşime gözümle işaret yaparım. }\end{array}$ & & .40 & & $.52 * *$ \\
\hline 42. Eşimin anne babalığa ilişkin kararlarını çürütmeye çalışırım. & & .40 & & $.50 * *$ \\
\hline 6. Çocuk bakımıyla ilgili eşimin bitirdiği işleri ben yeniden yaparım. & & .38 & & $.49 * *$ \\
\hline $\begin{array}{l}\text { 8. Babasının yaptığı yanlışlar hakkındaki düşüncelerimi çocuğa } \\
\text { söylerim. }\end{array}$ & & .38 & & $.51 * *$ \\
\hline 32. Eşimin çocukla geçirdiği zamanı bölerim. & & .33 & & $.50 * *$ \\
\hline $\begin{array}{l}\text { 40. Eşimin anne babalık ile ilgili kararlarını (desteklemesem de) } \\
\text { destekliyormuş gibi görünürüm. }\end{array}$ & & .26 & & $.17^{*}$ \\
\hline 2. Anne babalık görevlerini eşimle işbirliği içinde yapmam. & & .19 & & $.15^{*}$ \\
\hline 36. Çocuğu eşimle vakit geçirmekten vazgeçiririm. & & .17 & & $.11 *$ \\
\hline 20. Çocukla etkileşime girdiğinde eşime alaycı yorumlar yaparım. & & .11 & & .13 \\
\hline
\end{tabular}


Tablo 2 Devamı. Anne Bekçiliği Ölçeği’nin Faktör Yapısı

\begin{tabular}{|c|c|c|c|c|}
\hline Maddeler & $\begin{array}{c}\text { Faktör } \\
\quad 1\end{array}$ & $\begin{array}{c}\text { Faktör } \\
2\end{array}$ & $\begin{array}{c}\text { Faktör } \\
3\end{array}$ & $\begin{array}{c}\text { Madde-Toplam Madde } \\
\text { Korelasyonları }\end{array}$ \\
\hline $\begin{array}{l}\text { 13. Çocuğa anne babalık yapma konusunda eşimle fikir alışverişi } \\
\text { yapmaktan kaçınırım. }\end{array}$ & & -.13 & & $.10^{*}$ \\
\hline 25. Eşimin çocukla vakit geçirme isteğini görmezden gelirim. & & .07 & & .10 \\
\hline 24. Eşimin çocukla yapmak istediklerini kontrol ederim. & & & .66 & $.48 * *$ \\
\hline 15. Eşimin çocukla etkileşimini denetlerim. & & & .61 & $.46 * *$ \\
\hline $\begin{array}{l}\text { 34. Anne babalık konusundaki kararların alınmasından eşimi } \\
\text { alıkoyarım. }\end{array}$ & & & .55 & $.69 * *$ \\
\hline 41. Kendi isteğimi eşime kabul ettiririm. & & & .53 & $.59 * *$ \\
\hline 19. Çocuk ile ilgili konularda son sözü ben söylerim. & & & .50 & $.60 * *$ \\
\hline 31. Eşimin çocukla geçirdiği zamanı denetlerim. & & & .49 & $.65 * *$ \\
\hline 4. Eşimi hizaya getiririm. & & & .48 & $.57 * *$ \\
\hline 38. Çocuğa nasıl babalık yapacağı konusunda eşime kurallar koyarım. & & & .43 & $.55 * *$ \\
\hline $\begin{array}{l}\text { 10. Eğer eşimin hoşlanmadığım bir şey yaptığını görürsem, eşimin } \\
\text { çocukla etkileşimini durdururum. }\end{array}$ & & & .22 & .11 \\
\hline $\begin{array}{l}\text { 3. Çocukla ne sıklıkta etkileşime girebileceği hakkında eşime kurallar } \\
\text { koyarım. }\end{array}$ & & & .15 & .14 \\
\hline 30. Eşimin çocuğu kendi bildiği şekilde yetiştirmesine izin veririm. (T) & & & .11 & $.19^{*}$ \\
\hline $\begin{array}{l}\text { 37. Çocukla ilgili bir problemin çözümü için eşimle birlikte çalışırım. } \\
\text { (T) }\end{array}$ & & & .10 & $.19^{*}$ \\
\hline Cronbach Alfa & .81 & .66 & .74 & \\
\hline
\end{tabular}

Not 1. $* p<.05, * * p<.01$

Not 2. Faktör 1: Teşvik, Faktör 2: Engel, Faktör 3: Kontrol.

Not 3. (T) ile gösterilen maddeler ters puanlanan maddelerdir.

Not 4. 30'un üzerinde faktör yükleri ve madde-toplam madde korelasyonları koyu olarak gösterilmiştir.

Tablo 3. Kriter Geçerliğine İlişkin Korelasyon Katsayıları ve Ölçek Bilgileri ( $\mathrm{n}=210)$

\begin{tabular}{|c|c|c|c|c|c|c|c|c|c|c|}
\hline & (1) & (2) & (3) & (4) & (5) & (6) & (7) & Ort. & $S$. & Ranj \\
\hline (1) BAKÖ Toplam Puanı & - & & & & & & & 146.28 & 5.17 & 87.0 \\
\hline (2) Keyfi Meşguliyet & $.69^{* *}$ & - & & & & & & 60.78 & 5.61 & 49.0 \\
\hline (3) İlgi ve Yakınlık & $.43^{* *}$ & $.37 * *$ & - & & & & & 56.66 & 6.20 & 59.0 \\
\hline (4) Temel Bakım & $.61^{* *}$ & $.43 * *$ & $.28 * *$ & - & & & & 28.84 & 16.17 & 32.0 \\
\hline (5) ABÖ-A Teşvik Boyutu & $.20^{*}$ & $.22 * *$ & $.27 * *$ & $.20 * *$ & - & & & 45.84 & 10.07 & 48.0 \\
\hline (6) ABÖ-A Engel Boyutu & $-.32 *$ & $-.15^{*}$ & $-.33 * *$ & $-.17 *$ & $-.31 * *$ & - & & 13.56 & 3.67 & 59.0 \\
\hline (7) ABÖ-A Kontrol Boyutu & $-.14^{*}$ & $-.10^{*}$ & $-.16^{*}$ & $-.14^{*}$ & $-.15^{*}$ & $.59^{* *}$ & - & 16.59 & 6.68 & 52.0 \\
\hline
\end{tabular}

Not. ${ }^{*} p<.05, * * p<.01$ 


\section{Tartıșma}

Bu çalışmada; annelerin babalar üzerinde kolaylaştırıcı, kontrolcü ya da engelleyici yöntemler kullanarak, baba çocuk ilişkisini etkileyen davranışlarını değerlendirmek için Puhlman ve Pasley (2017) tarafından geliştirilen Anne Bekçiliği Ölçeği Türkçeye uyarlanmıştır. Ülkemizde anne bekçiliğini annelerin gözünden değerlendirebilecek bir ölçek olmadığından, çalışma kapsamında ölçeğin anne formunun geçerlik güvenirlik analizlerine yer verilmiştir.

ABÖ-A'nın yapı geçerliğine ilişkin orijinal çalışmada bildirilen bulgular, mevcut çalışmada desteklenmiş ve doğrulayıcı faktör analizi (DFA) ile ölçeğin teşvik, engel ve kontrol olmak üzere üç faktörlü yap1 gösterdiği tespit edilmiştir. Araştırmacıların (Puhlman ve Pasley, 2017) 42 madde üzerinden yürüttükleri ilk doğrulayıcı faktör analizi sonucunda elde ettikleri 15 maddelik ABÖ-A'nın engel ve kontrol boyutlarını temsil eden gizil değişkenler arasındaki yapısal korelasyon değeri .82 olarak raporlanmıştır. Çoklu bağıntı sorununa (multicollinearity) işaret eden bu bulgunun yorumunda araştırmacılar, söz konusu boyutlar arasındaki ayırt ediciliğin artırılmasının gelecek çalışmalar için hedeflenmesi gerektiğini vurgulamışlardır. Mevcut çalışmada ise, doğrulayıcı faktör analizi sonrası engel ve kontrol alt boyutları arasındaki yapısal korelasyon değeri orijinal çalışmaya kıyasla daha düşük $(\mathrm{r}=.75)$ bulunmuştur ve bu bulgu araştırmacıların ölçeğin kuramsal arka planına dair beklentileri ile uyumlu görünmektedir.

Çalıșmada kriter geçerliğini belirlemek amacıyla, anne bekçiliği ile ilişkili olduğu bilinen baba katılım düzeyini ölçen BAKÖ’den yararlanılmıştır. Bu ölçeğin tercih edilmesindeki en temel neden, baba katılımının annenin bekçilik davranışları ile doğrudan ilişkili olduğu varsayımıdır. Orijinal çalışmada araştırmacılar (Puhlman ve Pasley, 2017); Allen ve Hawkins'in (1999) konu ile ilgili geliştirdikleri bir diğer Anne Bekçiliği Ölçeği'ni (Maternal Gatekeeping Scale - MGS) kullanmışlardır. Farklı kaynaklardan alınan verilerin güvenirlik açısından daha tatmin edici olacağı bildirildiğinden (Schenck ve ark., 2009), mevcut çalışmada kriter geçerliği için annenin bekçilik davranışlarından etkilenen baba katılım düzeyini, babaların bildirimleri ile değerlendiren BAKÖ kullanılmıştır. Bulgular, ABÖ-A'nın baba çocuk etkileşimini değerlendiren ölçeklerle ilişkisini inceleyen çalışmalarla paralellik göstermektedir (Altenburger, Schoppe-Sullivan ve Dush, 2018; Aydın ve Akgöz-Aktaş, 2017). BAKÖ toplam puanı ile ABÖ-A'nın teşvik alt boyutu $(\mathrm{r}=.20, \mathrm{p}<.05)$ arasında pozitif yönlü; engel $(\mathrm{r}=$ $-.32, \mathrm{p}<.001)$ ve kontrol alt boyutlar1 $(\mathrm{r}=-.14, \mathrm{p}<.05)$ arasında ise negatif yönlü ilişki bulunmuştur. Sonuçların kriter geçerliği açısından uygunluğunun yanı sıra dikkat çekici bir diğer bulgu, BAKÖ'nün babaların çocukları ile duygusal yakınlık kurmasını ifade eden ilgi ve yakınlik alt boyutunun, diğer alt boyutları olan temel bakım ve keyfi meşguliyete kıyasla, ABÖ-A'nın teşvik ve engel alt boyutları ile gösterdiği ilişkinin yüksek olmasıdır. Söz konusu bulgu çalışmanın ana hipotezlerinden biri olmamakla birlikte; annelerin babalar üzerindeki davranışlarının, babanın çocuğa bakım verme, onunla oyun oynama gibi fiziksel katılımlarının ötesinde esas olarak baba ile çocuk arasındaki duygusal yakınlık ile ilişkili olması açısından önem taşımaktadır. Annelerin baba çocuk ilişkisindeki bu kritik rolü, baba kırılganlığ hipotezini (father vulnerability) destekler görünmektedir (Cummings, Merrilees ve Ward, 2010; Cummings, Goeke-Morey ve Papp 2004). Bu hipotez; aile içi olumsuz koşulların baba çocuk arasındaki ilişkiyi anne çocuk ilişkisine k1yasla daha kolay yıprattığını ifade eder ve anne çocuk ilişkisinin sağlam temellerini annelerin eşlik ve annelik rollerini babalardan daha iyi ayırt edebilme becerilerine dayandırır (Krishnakumar ve Buehler, 2000). Mevcut araştırmada, baba çocuk arasındaki duygusal yakınlık ile annenin engelleyici bekçilik davranışları arasında negatif bir ilişki bulunması, söz konusu hipotezin sınanması için yeni bir araştırma alanı olarak görülmektedir. Bununla birlikte anne bekçiliği alt boyutlarından teşvik ve engel alt boyutları ile teşvik ve kontrol alt boyutları arasında negatif yönlü bir ilişki bulunmuşken (sırasıyla $\mathrm{r}=-.31$ ve $r=-.15$ ), engel ile kontrol alt boyutları arasında pozitif yönlü bir ilişki bulunmuştur $(r=.59)$. Orijinal çalışmacıların (Puhlman ve Pasley, 2017) ölçeğin alt boyutlarına ilişkin tanımlamaları da göz önüne alınarak, annelerin kontrol ve engel davranışlarını teşvik davranışlarından farklı olarak olumsuz algıladığ 1 ve engel ile kontrol davranışlarını daha benzer gördükleri söylenebilir.

Alt boyutların iç tutarlık katsayıları orijinalinde .72 ile .82 aralığında iken, mevcut çalışmada .66 ile .81 aralığında olduğu görülmüştür. Buna ek olarak yürütülen yarıya bölme iç tutarlık güvenirlik analizinde alt boyutların Guttman güvenirlik katsayılarının .60 ile .79 aralığında olduğu bulunmuştur. ABÖ-A'nın engel alt boyutunun güvenirlik katsayıları görece düşük olmakla birlikte, kabul edilebilir sınırlar içerisindedir (Schermelleh-Engel, Moosbrugger ve Müller, 2003). Gerek orijinal çalışmada (Puhlman ve Pasley, 2017) gerekse mevcut çalışmada en düşük iç tutarlığa sahip boyutun engel alt boyutu olduğu görüldüğünden, gelecek çalışmalarda annelerin engel davranışlarının tanımlanmasında daha hassas bir çalışma yürütülmesi hedeflenebilir.

Çalışmada ayrıca ABÖ-A'nın bazı demografik özelliklerle ilişkisi de incelenmiştir. Anne bekçiliğinin ebeveynlerin yaşı ve evlilik süresi ile ilişkili olmadığı; ebeveyn eğitim düzeyine göre ise farklılaşmadığı görülmüştür. Oysa Türkiye'de anne bekçiliğine ilişkin ilk 
ölçek uyarlama çalışmasını yapan Karabulut ve Şendil (2017), çalışmalarında bekçilik davranışlarının ebeveynlerin yaşına ve eğitim düzeylerine göre farklılaştığını bulmuşlardır. Mevcut çalışma bulgularının adı geçen araştırmacıların raporladığı bulgular ile uyum göstermemesinin bir nedeni, uyarlanan bekçilik ölçeklerinin farklı grupları kapsıyor olması olabilir. Mevcut çalışmada, bekçilik davranışları annelerin gözünden değerlendirilirken, Karabulut ve Şendil (2017) bekçilik davranışlarına maruz kalan babaların gözünden değerlendirme yapmışlardır. Bekçilik davranışlarının doğasına yönelik literatür açıklamaları ile de paralel olarak, anne bekçiliğine ilişkin çıktıların, etkileyen (anne) ve etkilenen (baba) algılarına göre farklılık gösterebileceği düşünülmektedir (Fagan ve Barnett, 2013; Puhlman ve Pasley, 2017). Bunlara ek olarak mevcut çalışma bulgularının geçmiş çalışmalarla kıyaslanabilirliği sınırlıdır. Önceki anne bekçiliği çalışmalarında teşvik, engel ve kontrol alt boyutları ile çalışılarak demografik özellikler incelenmemiştir. Ayrıca Puhlman ve Pasley (2017), geliştirdikleri Anne Bekçiliği Ölçeği'nin tek tek alt boyutlara dayanılarak yorumlanmasını uygun bulmamaktadır. Dolayısıyla bulguların genellenebilirliği için daha geniş örneklemlerde, bekçilik alt türleri oluşturularak, anne ve babalar için kavramın nasıl algılandığının belirlenmesi ve bu algıyı biçimlendiren cinsiyet rolleri, evlilik ilişkisi gibi ebeveynlere ilişkin bilgilerin de değerlendirilmesine ihtiyaç duyulmaktadır.

Mevcut çalışmada anne bekçiliğinin bazı değişkenler ile ilişkili olduğu da saptanmıştır, örneğin annelerin babalar üzerindeki kontrol düzeyleri, kız çocuk sahibi annelerde daha yüksek bulunmuştur. Söz konusu bu bulgu kültüre özgü ebeveynlik pratiklerini konu alan bazı çalışmalarla benzerlik göstermektedir. Kendi yetiştirilme biçimleri ile ilişkili olarak ebeveynlerin kız ve erkek çocuklarına farklı duygu sosyalleştirme yaptığı, oyunlar oynadığı ve bakım verdiği bilinmektedir (Bowie ve ark., 2013). Üstelik babaların erkek çocuklarına bakım sağlarken daha özgüvenli olduklarını bildiren bazı çalışmalar da bulunmaktadır (Morman ve Floyd, 2002). Sonuçlardan hareketle söz konusu bulgu, annelerin geleneksel cinsiyet rollerine bağlı olarak, kız çocuklarının yetiştirilmesinde babalık davranışlarını daha çok takip edip yönetmeleri ile ilişkilendirilebilir. Mevcut çalışmada iş yükü artan annelerin babaları daha fazla teşvik etmeleri ve çalışma saati fazla olan babalar ile çocuklarını bir araya getirme çabaları, ev içinde biriken iş yükünün paylaşılması ve çocukların baba ile geçirecekleri kısıtlı vaktin değerlendirilmesi adına anneler tarafından alınan tedbirler gibi görünmektedir.

Puhlman ve Pasley'in (2013) önerdiği sınıflandırmaya uygun olarak oluşturulan anne bekçiliği türlerinin sıklığına ilişkin bulgularda; baba katılımından hoşlanan ve aile içi iletişimde 'uzman' olan kolaylaştırıcı bekçi annelerin, sınıflandırmalar arasında en yüksek oranda temsil edilenler (\%19.5) olduğu görülmüştür. Araştırmacıların (Puhlman ve Pasley, 2013) özellikle çalışma saati fazla olan babalar için oldukça gerekli ve olumlu gördükleri bu bekçilik türünün, çalışma saati annelerin yaklaşık iki katı olan babalardan oluşan mevcut örneklemde ilk sırada yer alması, bu bekçilik alt türünün özelliklerini desteklemektedir. Bununla birlikte en olumsuz bekçilik alt türü olarak algılanan geleneksel sınır koyucu bekçilik türü mevcut çalışmada \%10 ile ikinci sırada yer almaktadır. Araştırmacılar engel ve kontrolün yüksek düzeylerde seyrettiği bu boyutu yalnızca olumsuz özellikleri ile değerlendirmenin yanlış olacağının altını çizerek, geleneksel sınır koyucu bekçilik alt türünde çocuk için zarar verici olabilecek babalık davranışlarının (örn., suça karışmış baba) üstesinden gelmeye çalışan bir annenin varlığından bahsetmişlerdir. Bu nedenle söz konusu alt türün sıklığı değerlendirilirken, babalar hakkında daha fazla bilgi toplanması gerekmektedir.

Sonuç olarak ABÖ-A'nın, annelerin babalar üzerindeki bekçilik davranışlarını değerlendirebilmek amacıyla, ülkemizde kullanılabilecek geçerli ve güvenilir bir ölçek olduğu düşünülmektedir. Bu çalışmanın örneklemi 4-6 yaş arası çocuğa sahip anneleri kapsamakta olup orijinal çalışmada araştırmacıların 3-7 yaş grubu çocuğa sahip ailelerle çalıştıkları bilinmektedir. Bununla birlikte, literatürde daha geniş yaş aralıklarını kapsayan anne bekçiliği ölçeğine rastlanmamıştır. Söz konusu eksikliğin olası bir nedeni, baba katılımına ve dolayısıyla baba çocuk ilişkisini değerlendirmeye yönelik ölçeklerin genellikle ilk çocukluk dönemini kapsayacak biçimde yapılandırılması olabilir (Sımsıkı ve Şendil, 2014). Oysa baba katılımı ve dolayısıyla da baba çocuk ilişkisine bir şekilde etkisi bulunan annelik davranışları -doğası ve biçimi değişerek de olsa- gelecek dönemlerde de çocuk için kuşkusuz devam etmektedir. Bu sebeple bekçilik davranışlarına ilişkin farklı gelişimsel dönemleri de içine alan ölçeklerin geliştirilmesinin gerekli olduğu düşünülmektedir. Bununla birlikte Anne Bekçiliği Ölçeği’nin babaların öz bildirimine dayalı formunun da Türkçeye uyarlanması ve birlikte kullanılmasının, ölçeği ve bulguları daha da değerli kılacağı düşünülmektedir. Konuyla ilgili olarak araştırmacılar (Puhlman ve Pasley, 2017), anneler ve babalar için aynı sorular ile hazırlanmış bir ölçek geliştirmek üzere yola çıkmışlar; ancak kavramın ve ebeveynlik davranışlarının doğası gereği bekçilik davranışlarına yönelik algıların anne babalar için farklı olduğunu görerek ayrı formlar geliştirmişlerdir. Gelecek çalışmalar için, hem annelerin bekçilik davranışlarını hem de babaların annelerin bekçilik davranışlarına yönelik algılarını değerlendirebilecek ölçeklerin geliştirilmesinin kıymetli olacağı düşünülmektedir. 


\section{Kaynaklar}

Allen, S. M., \& Hawkins, A. J. (1999). Maternal gatekeeping: Mothers' beliefs and behaviors that inhibit greater father involvement in family work. Journal of Marriage and the Family, 199-212.

Altenburger, L. E., Schoppe-Sullivan, S. J., \& Dush, C. M. K. (2018). Associations Between Maternal Gatekeeping and Fathers' Parenting Quality. Journal of Child and Family Studies, 27(8), 2678-2689.

Amato, P. R., \& Fowler, F. (2002). Parenting practices, child adjustment, and family diversity. Journal of marriage and family, 64(3), 703-716.

Aydın, A. ve Akgöz-Aktaş G. (2017). Anne Bekçiliği Üzerine Bir Derleme, Çocuk ve Gençlik Ruh Sağll$\breve{g}_{l}$ Dergisi: 24(3).

Belsky, J., Youngblade, L., Rovine, M., \& Volling, B. (1991). Patterns of marital change and parent-child interaction. Journal of Marriage and the Family, 487-498.

Bowie, B. H., Carrère, S., Cooke, C., Valdivia, G., McAllister, B., \& Doohan, E. A. (2013). The role of culture in parents' socialization of children's emotional development. Western journal of nursing research, 35(4), 514-533.

Bowlby, J. (1988). Developmental psychiatry comes of age. The American journal of psychiatry, 145(1), 1.

Caldera, Y. M. (2004). Paternal involvement and infant-father attachment: A Q-set study. Fathering, 2(2), 191-211.

Coley, R. L., \& Morris, J. E. (2002). Comparing father and mother reports of father involvement among low-income minority families. Journal of Marriage and Family, 64(4), 982-997.

Cox, M. J., Paley, B., \& Harter, K. (2001). Interparental conflict and parent-child relationships. Interparental conflict and child development: Theory, research, and applications, 249-272.

Cummings, E. M., Goeke-Morey, M. C., \& Papp, L. M. (2004). Everyday marital conflict and child aggression. Journal of abnormal child psychology, 32(2), 191-202.

Cummings, E. M., Merrilees, C. E., \& George, M. W. (2010). Fathers, marriages, and families. The role of the father in child development, 154-176.

De Luccie, M. F. (1995). Mothers as gatekeepers: A model of maternal mediators of father involvement. The Journal of Genetic Psychology, 156(1), 115131.

Dollahite, D. C., \& Hawkins, A. J. (1997). Generative Fathering: Beyond Deficit Perspectives (Current Issues in the Family). Sage Publications.

Downer, J., Campos, R., McWayne, C., \& Gartner, T.
(2008). Father involvement and children's early learning: a critical review of published empirical work from the past 15 years. Marriage \& Family Review, 43(1/2), 67-108.

Dubowitz, H., Black, M. M., Cox, C. E., Kerr, M. A., Litrownik, A. J., Radhakrishna, A., ... \& Runyan, D. K. (2001). Father involvement and children's functioning at age 6 years: A multisite study. Child Maltreatment, 6(4), 300-309.

Fagan, J., \& Barnett, M. (2003). The relationship between maternal gatekeeping, paternal competence, mothers' attitudes about the father role, and father involvement. Journal of family issues, 24(8), 10201043.

Gaunt, R. (2008). Maternal gatekeeping: Antecedents and consequences. Journal of family issues, 29(3), 373-395.

Gaunt, R., \& Pinho, M. (2018). Do sexist mothers change more diapers? Ambivalent sexism, maternal gatekeeping, and the division of childcare. Sex Roles, 79(3-4), 176-189.

Hauser, O. (2012). Pushing daddy away? A qualitative study of maternal gatekeeping. Qualitative Sociology Review, 8(1).

Karabulut, H., ve Şendil, G. (2017). Annelik Bekçiliği Ölçeği'nin (ABÖ) Türkçe'ye Uyarlanması. Elektronik Sosyal Bilimler Dergisi, 16(61), 686-699.

Kennedy, M., Betts, L., Dunn, T., Sonuga-Barke, E., \& Underwood, J. (2015). Applying Pleck's model of paternal involvement to the study of preschool attachment quality: a proof of concept study. Early Child Development and Care, 185(4), 601-613.

Kline, R. B. (2011). Principles and practice of structural equation modeling. The Guilford Press, New York, 3rd edition.

Krishnakumar, A., \& Buehler, C. (2000). Interparental conflict and parenting behaviors: Ameta-analytic review. Family relations, 49(1), 25-44.

Kulik, L., \& Tsoref, H. (2010). The entrance to the maternal garden: Environmental and personal variables that explain maternal gatekeeping. Journal of Gender Studies, 19(3), 263-277.

Kulik, L., \& Sadeh, I. (2015). Explaining fathers' involvement in childcare: an ecological approach. Community, Work \& Family, 18(1), 19-40.

Lamb, M. E., Pleck, J. H., \& Levine, J. A. (1985). The role of the father in child development. In Advances in clinical child psychology (pp. 229-266). Springer, Boston, MA.

MacDonald, C. (2009). What's culture got to do with it? Mothering ideologies as barriers to gender equity. Gender equality: Transforming family divisions of labor, 411-34. 
Morman, M. T., \& Floyd, K. (2002). A “changing culture of fatherhood": Effects on affectionate communication, closeness, and satisfaction in men's relationships with their fathers and their sons. Western Journal of Communication (includes Communication Reports), 66(4), 395-411.

Paulson, J. F., Dauber, S. E., \& Leiferman, J. A. (2011). Parental depression, relationship quality, and nonresident father involvement with their infants. Journal of Family Issues, 32(4), 528-549.

Puhlman, D. J. (2013). Developing and testing a comprehensive measure of maternal gatekeeping. Doktora tezi, Florida State University. DigiNole veri tabanından erişildi. (Tez numarası 7559).

Puhlman, D. J., \& Pasley, K. (2013). Rethinking maternal gatekeeping. Journal of Family Theory \& Review, 5(3), 176-193.

Puhlman, D. J., \& Pasley, K. (2017). The Maternal Gatekeeping Scale: Constructing a Measure. Family Relations, 66(5), 824-838.

Roy, K. M., \& Dyson, O. L. (2005). Gatekeeping in context: Babymama drama and the involvement of incarcerated fathers. Fathering, 3(3), 289.

Sano, Y., Richards, L. N., \& Zvonkovic, A. M. (2008). Are mothers really "gatekeepers" of children? Rural mothers' perceptions of nonresident fathers' involvement in low-income families. Journal of Family Issues, 29(12), 1701-1723.

Schenck, C. E., Braver, S. L., Wolchik, S. A., Saenz, D., Cookston, J. T., \& Fabricius, W. V. (2009). Relations between mattering to step-and non-residential fathers and adolescent mental health. Fathering, $7(1), 70$.

Schermelleh-Engel, K., Moosbrugger, H., \& Müller, H. (2003). Evaluating the fit of structural equation models: Tests of significance and descriptive goodness-of-fit measures. Methods of psychological research online, 8(2), 23-74.

Schoppe-Sullivan, S. J., Brown, G. L., Cannon, E. A., Mangelsdorf, S. C., \& Sokolowski, M. S. (2008). Maternal gatekeeping, coparenting quality, and fathering behavior in families with infants. Journal of Family Psychology, 22(3), 389.

Seery, B. L., \& Crowley, M. S. (2000). Women's emotion work in the family: Relationship management and the process of building father-child relationships. Journal of Family Issues, 21(1), 100-127.

Sımsıkı, H., \& Şendil, G. (2014). Baba Katılım Ölçeği'nin (BAKÖ) Geliştirilmesi. Elektronik Sosyal Bilimler Dergisi, 49(49).

Stevenson, M. M., Fabricius, W. V., Cookston, J. T., Parke, R. D., Coltrane, S., Braver, S. L., \& Saenz, D. S. (2014). Marital problems, maternal gatekeeping attitudes, and father-child relationships in adolescence. Developmental Psychology, 50(4), 1208.

Tu, Y. C., Chang, J. C., \& Kao, T. F. (2014). A study on the relationships between maternal gatekeeping and paternal involvement in taiwan. Procedia-Social and Behavioral Sciences, 122, 319-328.

Uludağlı, N.P. (2017). Baba Katılımında Etkili Faktörler ve Baba Katılımının Baba, Anne ve Çocuk Açısından Yararları. Türk Psikoloji Yazıları. 20(39), 70-88.

Walker, A. J., \& McGraw, L. A. (2000). Who is responsible for responsible fathering? Journal of Marriage and family, 62(2), 563-569.

White, J. M., \& Klein, D. M. (2008). The systems framework. Family theories, 151-177. 


\section{Summary \\ Turkish Adaptation of Maternal Gatekeeping Scale: Validity and Reliability Study}

\author{
Güleycan Akgöz Aktaş \\ Mersin University
}

\author{
Arzu Aydin \\ Mersin University
}

\begin{abstract}
Although mothers are still being considered to be the primary caregivers for children in family structure, over the past four decades, father involvement researches have showed that active paternal involvement contributed to the positive development of children (Lamb, Pleck and Levine, 1985; MacDonald, 2009, Tu, Chang and Kao, 2014). Moreover, substantial literature presents that children whose fathers are involved are more likely to be securely attached to them, have more positive peer relations, experience more life satisfaction and have less behavioral problems. (e.g. Caldera, 2004; Dubowitz at all., 2001; Kennedy, Betts, Dunn, Sonuga-Barke and Underwood, 2015).

However, the researchers who investigate the variables that play a role in father involvement emphasized that maternal behaviors effect the interaction between father and his child (Coley and Morris, 2002; Dauber, Paulson and Leiferman, 2011). De Luccie (1995) first defined the concept of gatekeeping to express the role of mothers in the father-child relationship. Then Allan and Hawkins (1999) conceptualized maternal gatekeeping as some beliefs and behaviors that inhibit a collaborative effort between mothers and fathers in family work. In Fagan and Barnett's (2003) study, the scholars suggest that, mothers play a significant role in deciding how much time fathers spend with their children as well as their participation in house works. In this respect, the concept of maternal gatekeeping is defined as maternal behaviors that limit the interaction between father and his child, rather than maternal attempt that restrict father's involvement in family works (Gaunt, 2008; Fagan and Bernett, 2003). Maternal gatekeeping was known as maternal behaviors that negatively effect father-child interaction until 2000's then Walker and McGraw brought a new insight to the concept and stated that in addition to some negative effects, maternal behaviors may have some facilitative effects too. Some subsequent studies supported this point of view (e.g. Roy and Dyson,
\end{abstract}

2005; Sano, Richards and Zvonkovic, 2008). Puhlman and Pasley (2013) tried to explain this change in the concept together with the view of family system theory and feminist perspective. The researchers defined the maternal gatekeeping as a set of complex behavioral interactions between parents, where mothers affect father involvement by using control, restriction, and facilitation on father's caring behaviors and relationship with their children on a regular and consistent basis. Puhlman and Pasley's (2013) new model of maternal gatekeeping has three different dimensions (control, encouragement, and discouragement) and eight possible types (traditional gate blockers, passive gate snubbers, facilitative gate openers, and passive gate welcomers, confused gate managers, apathetic gate managers, opinionated gate watchers, invisible gate ignorers). In the literature, there are some studies that examined maternal gatekeeping in terms of parental and child characteristics. Karabulut and Şendil (2017) found that maternal gatekeeping was not related to the child's gender, economic status of the family, and the way parents work. Moreover, they reported that highly educated fathers are less exposed the gatekeeping behaviors by mothers.

Allen and Hawkins (1999) may have been the first researchers to develop an instrument, Maternal Gatekeeping Measure, designed to specifically measure maternal gatekeeping based on their three-dimensional approach. Another measurement tool is the Maternal Gatekeeping Scale (MGS), which is developed by Fagan and Barnett (2003) and examines the behavior of the mother directly on the father-child relationship. The adaptation study of the MGS for our country was carried out by Karabulut and Şendil (2017). In the adaptation study, unlike the original study, the scale items were applied not to mothers but to fathers in order to evaluate the maternal gatekeeping behaviors that they were exposed from the fathers' perspective. The newest scale that is called

Address for Correspondence: Res. Asst. Güleycan Akgöz Aktaş, Mersin University, Campus of Çiftlikköy, Faculty of Science and Letters, Department of Psychology, Mersin.

E-mail: glycnakgoz@gmail.com 
Maternal Gatekeeping Scale was developed by Puhlman and Pasley (2013). The main aim of the present study was to adapt of the scale in to Turkish and examine the psychometric properties. In addition, the relationship between maternal gatekeeping and the related demographic characteristics was investigated.

\section{Method}

\section{Participants}

This study included 210 parents with children (104 girls, 106 boys) aged 4-6 years who attend preschool in Mersin. Participants' ages ranged between 24-47 (M = $34.8, \mathrm{SD}=4.8)$ for mothers and, 28-61 $(\mathrm{M}=38.8, \mathrm{SD}=$ $6.1)$ for fathers.

\section{Measurements \\ Demographic Information Form}

Participants were asked to answer the questions about their education level, age, working hours, duration of marriage, sex of children, and child's order of birth.

\section{Father Involvement Scale}

Father Involvement Scale, a self-report scale, was developed by Simsıkı and Şendil (2014) to evaluate the father participation of children aged 3-6 years. This scale is a 5-point Likert type scale that consists of 37 items and three subscales (arbitrary occupation, primary care, attention and closeness). Cronbach's alpha was measured of .89 for arbitrary occupation, .83 for primary care, .85 for attention and closeness, and .92 for total in the original study.

\section{Maternal Gatekeeping Scale}

Maternal Gatekeeping Scale was developed by Puhlman and Pasley (2017) to evaluate the encouraging, controlling and restrictive behaviors of mothers on fathers. This scale consists of 42 items with three subscales (encouragement, discouragement, control) and each item is evaluated on a 7-point Likert type scale. In the original study, the Cronbach alpha values of the sub-dimensions were $.82, .72$ and .77 respectively.

\section{Procedure}

The analyses include the validity and reliability studies of the MGS-M, as well as the relationship of the scale with some demographic characteristics and the classified of subcategories of maternal gatekeeping based on intersection of subscales. SPSS 20 was used for descriptive analyses, reliability coefficients and correlation analysis and $\mathrm{R}$ packet program was used for confirmatory factor analysis.

\section{Results}

According to confirmatory factor analysis (CFA), the overall model was fit the data with the remaining 29 items after removal of substances with a low level of substance load $\left(\chi^{2}[374, \mathrm{~N}=210]=604.592, \chi^{2} / d f=\right.$ $1.61, \mathrm{RMSEA}=.05, \mathrm{GFI}=.89, \mathrm{AGFI}=.87, \mathrm{CFI}=.86)$.

Father Involvement Scale was used for the criterion validity. The scale was found to be positively correlated with the encouragement $(\mathrm{r}=.20, \mathrm{p}<.05)$, and a negatively correlated with the discouragement $(r=-.32$, $\mathrm{p}<.001)$ and a negatively correlated with the control ( $\mathrm{r}$ $=-.14, \mathrm{p}<.05)$.

Cronbach's Alphas were calculated in order to examine the internal consistency of the MGS-M. The values were found as .81 for encourage, .66 for discourage and .74 for control. In order to determine whether the answers to the scale were free from random errors, an equivalent halves method was used. The results show that the Guttman reliability coefficients were .79 for the encouragement, .60 for the discouragement, and .74 for the control.

MGS-M was examined according to some demographic characteristics. The results showed that subscales of MGS-M were not correlated with the age of the parents and the duration of marriage. Similarly, mothers' encourage, discourage and control levels were not differed according to parents' educational level.

T-test analyses showed that mothers had higher control behaviors for daughters. In addition, as the number of children increases, mothers' encouraging behavior also increases. Similarly; mothers who have long working hours encourage their partners more, and fathers who have long working hours are encouraged more by their partners.

As in the original study, maternal gatekeeping was classified in 8 sub-categories by crossing 3 sub-dimensions and frequency values were examined. The most common maternal gatekeeping type is $19.5 \%$ of the sub-categories were found to be facilitative gate opener.

\section{Conclusion}

The findings of the current study show that the Turkish version of the MGS-M has acceptable levels of reliability and validity. However, the Turkish adaptation of fathers' self-report form of the Maternal Gatekeeping Scale and combined use of these scales together may make our knowledge, regarding the concept of maternal gatekeeping, more meaningful. For future studies, it is considered to be worthwhile to develop scales that can assess both gatekeeping behaviors of mothers and fathers' perceptions about gatekeeping behaviors of the mothers'. 